\title{
PROLONGATION OF THE FUNCTIONAL LIFE OF THE CORPUS LUTEUM IN SHEEP WITH EXPERIMENTAL UTERINE INFECTIONS
}

\author{
S. P. COUDERT AND R. V. SHORT \\ Department of Veterinary Clinical Studies, and \\ A.R.G. Unit of Reproductive Physiology and Biochemistry, Cambridge
}

(Received 18th Fune 1966)

\begin{abstract}
Summary. Inoculation of Corynebacterium pyogenes or Vibrio foetus into the uterine lumen of ewes on the 10th day of the oestrous cycle resulted in a prolongation in the life of the corpus luteum in six out of eleven animals. In three animals, the corpora were still fully functional on Day 21 of the cycle, as judged by their progesterone concentration, as well as the progesterone concentration in ovarian vein blood.
\end{abstract}

There is now strong circumstantial evidence that in the sheep and pig the corpus luteum regresses under the influence of a factor produced in the uterus (Anderson, Bowerman \& Melampy, 1963; Short, 1964; Du Buisson, 1965; Denamur, Martinet \& Short, 1966). Recently, Moor \& Rowson (1966a) have been able to demonstrate that in the non-pregnant ewe the 'lytic' effect is exerted by the uterine horn on the corpus luteum of the ipsilateral ovary. The same authors have shown that this effect of the uterus, which is associated with a decline in the progesterone secretion by the corpus luteum on the 15th day of the cycle, can be overcome by transferring an embryo to the uterus as late as the 12th day of the cycle (Moor \& Rowson, 1966b).

In addition to hysterectomy and the presence of an embryo, the life of the corpus luteum can be prolonged by a number of non-specific corrosives or irritants injected into the uterine lumen of gilts (Anderson, Butcher \& Melampy, 1961). We therefore decided to investigate the effects of experimental uterine infections on the life-span of the corpus luteum.

Eleven Welsh Mountain sheep were run with a raddled vasectomized ram and checked twice daily for signs of oestrus. After two control cycles, which all fell within the normal 16- to 17-day range, the animals were laparotomized on the 10th day of the treatment cycle, and a suspension of bacteria in $1 \mathrm{ml}$ of Hartley's broth was injected into the uterine horn adjacent to the ovary bearing a corpus luteum. The corpus luteum was marked with Indian ink, and the abdominal incision was then sutured and covered with an adhesive bandage. No antibiotics were used.

Three sheep were infected with Corynebacterium pyogenes (1 to $2 \times 10^{9}$ organisms/animal). This resulted in a great distension of the uterus with pus, and 
we decided therefore to try a less pyogenic organism, namely, Vibrio foetus ( $14 \times 10^{9}$ organisms/animal) in the subsequent experiments.

The infected ewes were run with a raddled vasectomized ram and checked twice daily for oestrus. If they had not shown any signs of heat within 11 days of the operation, i.e. by the 2 lst day of the cycle, a laparotomy was performed, and blood was obtained from one of the veins draining the ovary with the marked corpus luteum. The animals were then killed under the anaesthetic. Part of the uterus was fixed in Bouin's solution or formal saline for histological examination. The marked corpus luteum was enucleated from the ovary, and stored frozen until required for progesterone determinations. Progesterone was measured in the ovarian vein plasma and luteal tissue by the methods of Short (1958) and Rowlands \& Short (1959), with the addition of an internal isotope standard of $7-{ }^{3} \mathrm{H}$ progesterone to correct for extraction losses. If too little progesterone was present for estimation by ultraviolet spectrophotometry, an internal standard of 20 $\beta$-acetoxypregn-4-en-3-one was added to the eluate from the paper chromatogram, and final quantitation carried out by gas chromatography. The results of plasma and luteal progesterone determinations were compared with the normal values published previously by Short (1964) and Deane, Hay, Moor, Rowson \& Short (1966).

Two of the three ewes infected with Corynebacterium pyogenes had not returned to oestrus by the 21 st day after ovulation, and on laparotomy their uteri were found to be considerably distended by pus. The corpus luteum of one ewe (No. 575) was still fully active, as indicated by the progesterone concentration in ovarian vein blood. In the other ewe (No. 586), however, the corpus luteum had already begun to regress (see Table 1 ).

Four of the eight ewes infected with Vibrio foetus did not return to oestrus by the 21st day of the cycle, and two other animals exhibited prolonged cycles of 19 and 20 days respectively. In three out of the four animals examined on Day 21, the corpora lutea appeared to be fully functional (see Table 1). In contrast to the Corynebacterium pyogenes group, the uteri of the Vibrio foetusinfected animals were not noticeably distended, and contained only a slight amount of exudate with a few clots of pus. In five infected animals (575, $580,578,588$ and 574) the endometrium and uterine glands showed signs of acute inflammation with leucocytic infiltration, micro-abscesses, and submucosal oedema.

No control animals were included in the present series, since it has been shown by Moor \& Rowson (1966c) that cycle lengths in sheep are virtually unaffected by laparotomy and flushing the uteri with saline or serum.

Our results leave little doubt that a uterine infection with either $C$. pyogenes or $V$. foetus can cause a significant prolongation of the life of the corpus luteum in some ewes. The mechanism underlying this phenomenon remains to be explored. In any case it seems unlikely that the effect is due to uterine distension as such, since none of the $V$. foetus-infected animals had an enlarged uterus, and uterine distension with foreign bodies on the 8th and 12th days of the cycle in sheep usually has no effect on cycle length (Inskeep, Oloufa, Howland, Pope \& Casida, 1962; Moor \& Rowson, 1966c).

It is well known that in cattle (Rowson, Lamming \& Fry, 1953), rabbits 
(Hawk, Turner \& Sykes, 1960) and probably also in sheep (Hawk, Brinsfield \& Righter, 1963; Brinsfield, Hawk \& Leffel, 1963), the uterus becomes more susceptible to infection when a corpus luteum is present in the ovary. With the corpus luteum rendering the uterus susceptible to infection, and the uterine infection prolonging the life of the corpus luteum, something of a vicious circle

TABLE 1

GYGLE LENGTH AND LUTEAL AGTIVITY IN SHEEP EXPERIMENTALLY INFEGTED WITH Corynebacterium pyogenes OR Vibrio foetus ON DAY 10 OF THE OESTROUS CYCLE

\begin{tabular}{|c|c|c|c|c|}
\hline \multirow[t]{2}{*}{ Ewe No. } & \multirow{2}{*}{$\begin{array}{l}\text { Infecting } \\
\text { organism }\end{array}$} & \multirow{2}{*}{$\begin{array}{c}\text { Treatment cycle } \\
\text { length (days) }\end{array}$} & \multicolumn{2}{|c|}{ Progesterone concentration on Day 21 of treatment cycle } \\
\hline & & & $\begin{array}{l}\text { Ovarian vein blood } \\
(\mu g / 100 \mathrm{ml} \text { plasma })\end{array}$ & $\begin{array}{c}\text { Corpus luteum } \\
(\mu \mathrm{g} / \mathrm{g} \text { tissue })\end{array}$ \\
\hline $\begin{array}{l}575 \\
586 \\
585\end{array}$ & $\begin{array}{l}\text { C. pyogenes } \\
\text { C. pyogenes } \\
\text { C. pyogenes }\end{array}$ & $\begin{array}{r}>21 \\
>21 \\
17\end{array}$ & $\begin{array}{c}74 \cdot 5^{*} \\
3 \cdot 7^{*} \\
-\end{array}$ & $\begin{array}{l}- \\
-\end{array}$ \\
\hline $\begin{array}{l}574 \\
582 \\
581 \\
572 \\
573\end{array}$ & $\begin{array}{l}V . \text { foetus } \\
V . \text { foetus } \\
V . \text { foetus } \\
V . \text { foetus } \\
V . \text { foetus }\end{array}$ & $\begin{array}{r}>21 \\
>21 \\
>21 \\
> \\
\quad 21 \\
16 \\
19 \\
14 \\
20\end{array}$ & $\begin{array}{c}106 \cdot 6 \\
102 \cdot 1 \\
206 \cdot 8 \\
- \\
- \\
- \\
- \\
-\end{array}$ & 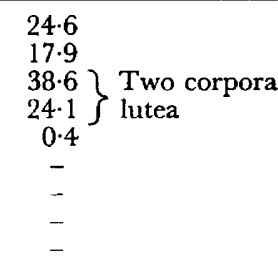 \\
\hline
\end{tabular}

* Estimation carried out on whole blood, and the values for plasma calculated assuming that packed cell volume of blood is $38 \%$ and that no progesterone is present in the red cells.

may thus be set up. Clinical evidence suggests that in cattle, uterine infections are often associated with irregular oestrous cycles and maintained corpora lutea (Roberts, 1956).

One of us (S.P.C.) acknowledges an Anglo-French Clinical Research Grant, awarded jointly by the Medical Research Council and the Institut National de la Santé et de la Recherche Médicale. We are also greatly indebted to Mr L. E. A. Rowson and Dr R. M. Moor for their surgical help, and to Dr M. A. Soltys for supplying us with the bacterial cultures. Dr A. R. Jennings kindly examined the histological sections of the uteri, and Dr T. Mann read the manuscript and made a number of helpful suggestions.

\section{REFERENCES}

Anderson, L. L., Butcher, R. L. \& Melampy, R. M. (1961) Subtotal hysterectomy and ovarian function in gilts. Endocrinology, 69, 571 .

Anderson, L. L., Bowerman, A. M. \& Melampy, R. M. (1963) Neuro-utero-ovarian relationships. In: Advances in Neuroendocrinology, chap. 11. Ed. A. V. Nalbandov. University of Illinois Press, Urbana, Illinois.

Brinsfield, T. H., Hawk, H. W. \& Leffel, E. C. (1963) Control by ovarian hormones of the inflammatory response in the sheep uterus. 7. Reprod. Fert. 6, 79.

Deane, H. W., Hay, M. F., Moor, R. M., Rowson, L. E. A. \& Short, R. V. (1966) The corpus luteum of the sheep: relationship between morphology and function during the oestrous cycle. Acta endocr., Copenh. 51, 245. 
Denamur, R., Martinet, J. \& Short, R. V. (1966) Sécrétion de la progestérone par les corps jaunes de la brebis après hypophysectomie, section de la tige pituitaire et hystérectomie. Acta endocr., Copenh. 52, 72.

Du Bursson, F. Du M. (1965) Le contrôle de la fonction lutéale chez la truie. Proc. 2nd int. Congr. Endocrinology, London; no. 83, p. 680. Excepta Medica Foundation.

Hawk, H. W., Brinsfield, T. H. \& Righter, H. F. (1963) Control by ovarian hormones of vascular permeability in normal and experimentally infected sheep uteri. F. Reprod. Fert. 6, 71.

Hawk, H. W., Turner, G. D. \& Sykes, J. F. (1960) The effects of various hormones on the uterine defense mechanism during the early stages of induced infection $A m$. F. vet. Res. 21, 544.

Inskeep, E. K., Oloufa, M. M., Howland, B. E., Pope, A. L. \& Casida, L. E. (1962) Effect of experimental uterine distension on estrual cycle lengths in ewes. F. Anim. Sci. 21, 331.

Moor, R. M. \& Rowson, L. E. A. (1966a) Local uterine mechanisms affecting luteal function in the sheep. F. Reprod. Fert. 11, 307.

Moor, R. M. \& Rowson, L. E. A. (1966b) The corpus luteum of the sheep: functional relationship between the embryo and the corpus luteum. 7. Endocr. 34, 233.

Moor, R. M. \& Rowson, L. E. A. (1966c) The corpus luteum of the sheep: effect of the removal of embryos on luteal function. F. Endocr. 34, 497.

RoberTs, S. J. (1956) Veterinary obstetrics and genital diseases, p. 301. Edwards Brothers, Ann Arbor, Michigan.

Rowlands, I. W. \& Short, R, V, (1959) The progesterone content of the guinea pig corpus luteum during the reproductive cycle and after hysterectomy. F. Endocr. 19, 21.

Rowson, L. E. A., Lamming, G. E. \& FRy, R. N. (1953) The relationship between ovarian hormones and uterine infection. Vet. Rec. 65, 335.

Short, R. V. (1958) Progesterone in blood. 1. The chemical determinations of progesterone in peripheral blood. 7. Endocr. 16, 415.

Short, R. V. (1964) Ovarian steroid synthesis and secretion in vivo. Recent Prog. Horm. Res. 20, 303. 